Relations industrielles

Industrial Relations

\title{
Déontologie, Rapport du groupe consultatif de déontologie, Conseil des Arts du Canada, Ottawa, 1977, 36 pp.
}

\section{Gilles Dussault}

Volume 32, numéro 2, 1977

URI : https://id.erudit.org/iderudit/028793ar

DOI : https://doi.org/10.7202/028793ar

Aller au sommaire du numéro

Éditeur(s)

Département des relations industrielles de l'Université Laval

ISSN

0034-379X (imprimé)

1703-8138 (numérique)

Découvrir la revue

Citer ce compte rendu

Dussault, G. (1977). Compte rendu de [Déontologie, Rapport du groupe consultatif de déontologie, Conseil des Arts du Canada, Ottawa, 1977, 36 pp.] Relations industrielles / Industrial Relations, 32(2), 286-287.

https://doi.org/10.7202/028793ar

Tous droits réservés @ C Département des relations industrielles de l'Université Laval, 1977
Ce document est protégé par la loi sur le droit d'auteur. L’utilisation des services d'Érudit (y compris la reproduction) est assujettie à sa politique d'utilisation que vous pouvez consulter en ligne.

https://apropos.erudit.org/fr/usagers/politique-dutilisation/ 
négliger l'aspect administratif de la gestion des ressources humaines qui traite habituellement des objectifs et des politiques, du partage des responsabilités; et, plus précisément, de la gestion prévisionnelle des effectifs. Sans me faire le défenseur d'un enseignement théorique à outran$\mathrm{ce}$, je dois souligner que, même si tous les exercices sont pratiques et appropriés, ils ne sont pas suffisants pour permettre à l'étudiant ou à celui qui débute d'accéder à une vision cohérente et globale du domaine de la gestion des ressources humaines.

C'est une faiblesse qui peut être tournée en un avantage si l'on considère que le recueil laisse une grande marge de manœuvre au professeur qui tient à diffuser sa vision personnelle des choses et de recommander à ses étudiants les auteurs qu'il préfère ou encore qu'il connait bien.

Université Laval

Laurent BÉLANGER

Bibliography of Industrial Relations in the Railroad Industry, by James $\mathrm{O}$. Morris, Ithaca, N.Y., New York State School of Industrial and Labor Relations, 1975, $153 \mathrm{p}$.

Cet ouvrage est le douzième dans la série de bibliographie que publie la New York State School of Industrial and Labor Relations de l'Université Cornell. Il porte sur les relations industrielles dans l'industrie ferroviaire aux États-Unis.

Par «industrie ferroviaire», on entend le réseau des chemins de fer à l'exclusion du transport urbain et de la fabrication du matériel.

Le terme «relations industrielles" est pris ici dans son sens le plus large, c'està-dire que, loin de se limiter uniquement à la négociation collective ou aux rapports syndicaux-patronaux, il englobe tout ce qui se rattache aux relations professionnelles (emploi, chômage, syndicalisme, négociation, grève, médiation) ou qui les influence (législation, action gouvernementale, changements technologiques) ou qui, enfin, en est la conséquence (programmes de retraite, accidents du travail, etc.).

La bibliographie est divisée en chapitres selon six catégories de sources: a) bibliographie; b) les manuscrits; c) les livres, brochures et thèses; d) les périodiques; e) la documentation législative; 7) les publications gouvernementales. À l'intérieur de chacun des chapitres, la matière est ordonnée selon le plan suivant: généra- lités; les chemins de fer et le gouvernement ; le management ; la main-d'ceuvre; les conditions de travail; les syndicats et les travailleurs; la législation du travail ; les relations du travail ; les programmes de retraité et de protection des travailleurs.

La présentation a été effective en suivant le Manual of Style (12 édition) des Presses de l'Université de Chicago. Bien qu'il ne s'agisse pas d'une bibliographie annotée, lorsque cela s'avérait nécessaire quelques explications ont été ajoutées.

L'auteur nous avertit qu'il n'a pas la prétention d'offrir un ouvrage exhaustif sur le sujet mais, par ailleurs, que celui-ci dépasse largement ce que l'on qualifie habituellement de représentatif.

Naturellement cette bibliographie ne s'en tient qu'aux publications des ÉtatsUnis. Elle est cependant un instrument précieux et indispensable à tous les chercheurs qui auront à travailler sur cette question.

Université Laval

Gérard DION

Déontologie, Rapport du groupe consultatif de déontologie, Conseil des Arts du Canada, Ottawa, 1977, 36 pp.

Devant le nombre sans cesse croissant de demandes de subventions pour des recherches en sciences humaines mettant en cause «les intérêts et les préoccupations légitimes de sujets humains», le Conseil des Arts du Canada a formé un groupe de travail pour examiner les aspects éthiques de ce type de recherche et élaborer, si possible, un ensemble de règles de conduite à suivre en cette matière. Son rapport se présente sous la forme de réflexions générales sur la nécessité de l'obtention du consentement éclairé des sujets, le rejet catégorique du recours à toute forme de duperie ou d'artifices, le respect de l'intimité de ceux qui prêtent leur concours à une recherche ainsi que sur la confidentialité à leur garantir. Ces réflexions, qui sont assorties de recommandations précises, ont conduit le groupe de travail, composé d'universitaires d'origines diverses, à s'interroger sur les applications des principes généraux d'éthique à des situations particulières: acquisition et préservation de biens culturels, en anthropologie et en archéologie, recherches sur des populations «captives", sur les enfants, sur des cultures et groupes ethniques étrangers.

Les règles fondamentales que propose le Conseil des Arts aux chercheurs qui 
comptent travailler avec des sujets humains sont claires: l'intérêt du sujet prime tout. Dans tous les cas, lui-même ou un représentant autorisé doit consentir explicitement à participer à une recherche, sans contrainte aucune et en pleine connaissance de cause et en tout temps, il doit pouvoir se désister si tel est son désir. Des règles strictes doivent s'appliquer pour assurer l'anonymat et la confidentialité au sujet participant et le chercheur doit se faire un devoir de respecter l'intimité de ceux dont il requiert la collaboration. Les notions d'intimité, d'anonymat s'interprètent toujours du point de vue du sujet et non de celui de l'observateur, surtout dans les cas où l'enquêteur considère une population d'une culture différente de la sienne.

Ces règles déontologiques doivent guider le chercheur au moment de la conception de son projet et au moment de la rédaction de la demande de subvention. Sa demande sera préalablement soumise à un comité d'évaluation, dont le Conseil suggère la formation dans chacun des établissements universitaires qui l'examinera à la lumière des règles déjà énoncées; le comité pourra refuser un projet, demander des modifications ou encore demander des rapports périodiques au chercheur pour pouvoir suivre le déroulement de son travail.

Toutefois l'objectif qu'entend poursuivre le Conseil n'est pas tant de soumettre les chercheurs à des règlements rigides que de les amener à prendre conscience des exigences éthiques de leurs activités et à s'y soumettre spontanément. Parmi les moyens d'atteindre cet objectif, il y a sûrement la diffusion la plus large possible du rapport du groupe consultatif de déontologie; nous suggérions aussi que le Conseil prépare un dossier qui présente des exemples de cas soumis aux comités d'évaluation et qui peuvent servir à guider les réflexions des chercheurs. Une autre suggestion serait de s'interroger sur la formation déontologique des chercheurs en sciences humaines; dans la mesure où les établissements d'enseignement avancé ne sensibilisent pas leurs étudiants à ces questions, la tâche du Conseil sera beaucoup plus grande.

\section{Université Laval}

Gilles DUSSAULT

Cyclical Instability in Residential Construction in Canada, by Joseph $\mathrm{H}$. Chung, Ottawa (Economic Council of Canada, 1976), 139 pp.
This is another in the series of studies produced for the Economic Council of Canada's Reference on Construction Instability in Canada. Its main purpose is to assess some of the causes and effects of cyclical instability in residential construction in Canada and suggest measures for creating greater stability in housing construction.

One might ask, why study instability in the residential sector? A major reason is that the residential sector accounts for a disproportionate share of instability in the construction industry. Fluctuations in housing activity tend to create inefficiencies in both product and labour markets and thus contribute to the rise in housing costs.

The book is divided into five chapters. In Chapter 1 , the author provides an overview of the meaning and dimensions of instability and introduces numerous measurements of the business cycle. The interaction of general business cycles and housing-start cycles are discussed in detail. A major finding is that housing activity "varies considerably from one dwelling type to another, from one region to another, and from one period to another'. Because of these wide cyclical fluctuations, the formulation of national policy requires a careful analysis of disaggregated data.

Chapter 2 discusses the determinants of residential construction activity. The analysis of long-run growth in dwelling units considers the influence of demographic factors, and income, price, and credit variables. Cyclical fluctuations are assessed in terms of the availability of mortgage funds, interest rates and monetary policy. The author cogently points out that current views and previous empirical analyses of the determinants of residential construction are not in agreement regarding the relative influence of these factors.

The next two chapters of the book are more technical. An econometric model of cyclical instability is developed and the results are presented. In Chapter 5 the author considers the arguments - both pro and con - for stabilizing residential construction and considers alternative directions for policy makers. He concludes that there is a need to produce greater stability in residential construction and that efforts should be made to insulate the residential sector from monetary policy.

This book is well organized and should prove to be a valuable reference volume. It is likely to be of interest to academics, government officials and practitioners in financial institutions and the housing in- 